\title{
Assessment of radionuclide export from Chernobyl zone via birds 18 years following the accident
}

\author{
S. Gaschak ${ }^{1}$, M. Bondarkov¹, Ju. Makluk ${ }^{1}$, A. Maksimenko ${ }^{1}$, V. Martynenko ${ }^{1}$, \\ I. Chizhevsky ${ }^{1}$ and Ta. Mousseau ${ }^{2}$ \\ ${ }^{1}$ Chornobyl Center for Nuclear Safety, Radioactive Waste and Radioecology, International \\ Radioecology Laboratory, 07100 Slavutych, Ukraine \\ ${ }^{2}$ University of South Carolina, Columbia, SC 29208, USA
}

\begin{abstract}
In 2003-2005 we investigated current contamination of small birds in Chornobyl zone, as vertebrates with the largest diversity and biomass, and inherent season migrations. A whole-body live counting method was used to analyze ${ }^{90} \mathrm{Sr}$ and ${ }^{137} \mathrm{Cs}$ in the birds. Total number and biomass of small birds was estimated using 1) data of birds population density in different kinds of biogeocenosis, 2) ratio of biogeocenosises area at the zone, 3) data of biomass of species. We used GIS application, an electronic map of the Chernobyl zone contamination and ${ }^{90} \mathrm{Sr}$ and ${ }^{137} \mathrm{Cs}$ transfer factor "soil-bird" to calculate average contamination of birds at any location regardless they had been caught there or hadn't. According to our assessment total number of small birds by the end of breeding season in 2004 amount to at least 5.14 million individuals, total biomass -134 tons, total stock of radionuclides $-74.7 \mathrm{MBq}^{90} \mathrm{Sr}$ and $55 \mathrm{MBq}^{137} \mathrm{Cs}$. All these birds can export no more $80 \%$ of their initial contamination outside the zone. Together with total avian flow yearly passed through the region $\left(2600 \mathrm{~km}^{2}\right)$ they export up to $2.47 \mathrm{GBq}^{137} \mathrm{Cs}$ and $3.70 \mathrm{GBq}^{90} \mathrm{Sr}$.
\end{abstract}

\section{INTRODUCTION}

During the last decade evaluation of radionuclide export via birds was fulfilled at the assessment of different ways of radionuclide export from the Chernobyl zone (e.g. [1]). These values amount to approx. $15-67 \mathrm{GBq}{ }^{90} \mathrm{Sr}$ and $56-204 \mathrm{GBq}{ }^{137} \mathrm{Cs}$, or, respectively, near $0.05-0.09 \%$ and $0.5-0.9 \%$ of annual total export from the Chernobyl zone. However these estimations were based on data by Frantsevich et al. [2], obtained in 1986-1988 without corrections related to temporal changes in radioecological conditions, leading to the question of how these earlier estimates relate to empirically derived measurements. Therefore in 2003-2005 we conducted a study of small passerines to determine actual contamination levels in these birds that inhabit the Chernobyl territory, since they are the largest group of local vertebrates, which could carry out radioactivity from the region.

\section{MATERIALS AND METHODS}

This study was conducted at several sites within the Chernobyl exclusion zone. Most birds were captured in May-June, during breeding season when they are most settled. We used a live counting method to determine whole body activity of ${ }^{90} \mathrm{Sr}$ and ${ }^{137} \mathrm{Cs}$. A detailed description of the methods and a generic description of the data obtained can be found in [3]. In total, 491 measurements were obtained $\left({ }^{90} \mathrm{Sr}\right.$ and ${ }^{137} \mathrm{Cs}$ each) for 44 species of birds.

In order to predict contamination of the birds at the locations which had not been involved into the study we used radionuclide transfer factor $(T F)$ 'soil-animal' calculated for real data. According to our analysis there were no evident distinctions between $T F$ of different species, therefore geometric average values were used for prediction (frequency distribution of both activity concentration values and $T F$ 
values had a pattern close to log-normal). In 2003-2005 the $T F$ amounted to $2.64 \times 10^{-3} \mathrm{~m}^{2} \mathrm{~kg}^{-1}$ and $0.70 \times 10^{-3} \mathrm{~m}^{2} \mathrm{~kg}^{-1}$ for ${ }^{90} \mathrm{Sr}$ and ${ }^{137} \mathrm{Cs}$, respectively [3]. Our approaches were based on the assumption that small size birds have relatively high metabolic rates [4]. We assumed that the half-life of ${ }^{90} \mathrm{Sr}$ and ${ }^{137} \mathrm{Cs}$ outtake $\left(\mathrm{T}_{1 / 2}\right)$ from birds is close to 5-10 and 1-2 days, respectively, i.e. similar to that for small mammals [5]. These rates presume rapid changes of activity concentration depending on radionuclide intake fluctuation. At these values, according to the classic model of trophic intake (e.g. [4]), quasiequilibrium state of the radionuclide accumulation will be reached by 17 to 34 and 4 to 7 days for ${ }^{90} \mathrm{Sr}$ and ${ }^{137} \mathrm{Cs}$, respectively, after the birds arrive in the contaminated environment. According to [6], nearly $80 \%$ of young of the year passerines survive to the start of fall migration period. To obtain an upper bound on our estimate of radionuclide export we also assumed that: 1) all adult birds survive the breeding season, 2) about $20 \%$ of the breeding species representing about $7 \%$ of the total bird biomass do not leave the region as resident ones (Gaschak, unpublished data); and 3) departure from the zone occurs over a 1 to 2 day time frame. Under these conditions departing birds will carry approximately $75 \%$ and $25 \%$ of their initial body burdens for ${ }^{90} \mathrm{Sr}$ and $25 \%$ for ${ }^{137} \mathrm{Cs}$, respectively (see $\mathrm{T}_{1 / 2}$ above). We estimated abundance and biomass of birds with respect to their relation to "phytocomplex" type (i.e. plant community) using known associations for this region [7]. Corresponding contamination data was derived from the Ukrainian Research Institute for Civil Defense of Population and Territories from Technogenic and Natural Emergencies (data were kindly provided by A. Arkhipov, N. Kuchma). These data describe 28 typical types of plant complexes on the total area 206383 ha (excluding large water bodies and an area 'nearest' to ChNPP that was decontaminated in 1986-1990). The dataset also included values for total deposition stock of ${ }^{90} \mathrm{Sr}$ and ${ }^{137} \mathrm{Cs}$ in each phytocomplex in 2004 year. Bird population densities were estimated using published data. For example, in the abandoned town of Pripyat (central part of the Chornobyl zone) in 1991-1997 the total bird density was 2.9-10.5 ind/ha [8]. In neighboring Belarus bird surveys conducted in 1988-1992 period there had the following densities (ind/ha): pine tree forest (7), flood-plane meadow (4), former villages (15), former fields (4) [9]. In similar regions of Russia and Ukraine the bird densities varied from $5 \mathrm{ind} / \mathrm{ha}$ in birch forest to $10 \mathrm{ind} / \mathrm{ha}$ in pine tree forest, and up to 2-3 times higher in broad-leaf forest (e.g. $[10,11])$. We also assumed that: 1) average live weight of birds from forest systems was 30 grams (since these bird communities consist of big thrushes and small warblers), and 15 grams for birds inhabiting open (or semi-open) areas; 2) birds population consists only of breeding pairs; 3) the average number of chicks which fledge was 4. More approaches will be given below during the results discussion.

\section{RESULTS AND CONCLUSIONS}

According to our calculations in 2004 small local birds carried nearly $75 \mathrm{MBq}$ of ${ }^{90} \mathrm{Sr}$ and $55 \mathrm{MBq}$ of ${ }^{137} \mathrm{Cs}$ (Table 1). If one follows the assumption of [2] that total biomass of small birds ('forest and steppe local birds') exceeds waterfowl biomass by 1.5 times, then the total stock of radionuclides in local avifauna can reach $112.5 \mathrm{MBq}$ for ${ }^{90} \mathrm{Sr}$ and $82.5 \mathrm{MBq}$ for ${ }^{137} \mathrm{Cs}$. This is similar to the total stock of radionuclides deposited in several square meters in the central, most contaminated area of the Chernobyl zone. More importantly, only $61 \%$ of ${ }^{90} \mathrm{Sr}$ and $20 \%$ of ${ }^{137} \mathrm{Cs}$ are exported away via birds leaving the territory during autumn seasonal migrations. In contrast, in 1987 local avifauna accumulated about 1.6-7.0 and 7.9-29.2 times more ${ }^{90} \mathrm{Sr}$ and ${ }^{137} \mathrm{Cs}$, respectively, due to a number of factors, but most importantly due to higher TFs. As can be seen from Table 1, the ${ }^{137} \mathrm{Cs}$ transfer factor decreased dramatically due to a decreased bioavailability of ${ }^{137} \mathrm{Cs}$ in soil, while the less remarkable decrease of $T F_{S r}$ can be explained by secondary elevation of ${ }^{90} \mathrm{Sr}$ availability in 1990-2000 [12].

Since in 1987-1992 knowledge about the pattern of radionuclide distribution within the Chernobyl zone was not very detailed, and researchers had to use preliminary data to generate best "guesses" [2]. Our estimates reflect revised estimates of abundances generated much more recently. Results of our recalculation almost completely coincide with value range reported earlier (Table 2). 
Table 1. Stock of ${ }^{90} \mathrm{Sr}$ and ${ }^{137} \mathrm{Cs}$ in biomass of local birds and export of the radionuclide via birds from the Chernobyl zone based on two studies (estimates made for small sized birds only).

\begin{tabular}{|l|c|c|}
\hline \multirow{2}{*}{\multicolumn{1}{|c|}{ Indices }} & \multicolumn{2}{c|}{ Source of data } \\
\cline { 2 - 3 } & {$[2]^{*}$} & Our data \\
\hline Year of the assessment & 1987 & 2004 \\
\hline Total area, ha & $206383^{*}$ & 206383 \\
\hline$T F_{S r}, m^{2} / \mathrm{kg}$ & $10.7 \times 10^{-3}$ (body) & $2.64 \times 10^{-3}$ (body) \\
\hline$T F_{C s}, \mathrm{~m}^{2} / \mathrm{kg}$ & $7.7 \times 10^{-3}$ (muscle) & $0.70 \times 10^{-3}$ (body) \\
\hline Total number, ind. & $412766^{*}$ & 5135500 \\
\hline Biomass, ton & $41.3^{*}$ & 134.4 \\
\hline Stock of ${ }^{90} \mathrm{Sr}$ in total biomass, $\mathrm{MBq}$ & $116.5-525.1^{*}$ & 74.7 \\
\hline Stock of ${ }^{137} \mathrm{Cs}$ in total biomass, $\mathrm{MBq}$ & $437.5-1604.5^{*}$ & 55.0 \\
\hline Export of ${ }^{90} \mathrm{Sr}$ via local birds, $\mathrm{MBq}$ & $70.8^{* *}$ & 45.4 \\
\hline Export of ${ }^{137} \mathrm{Cs}$ via local birds, $\mathrm{MBq}$ & $88.5^{* *}$ & 11.0 \\
\hline
\end{tabular}

* Values for 'forest and steppe local birds'(by [2]) were recalculated for the area 206383 ha in order to compare with our data.

** In the paper quoted here there is no direct estimation of radionuclides export via local birds. Therefore this value was calculated according to our procedure, as described in the text.

Table 2. ${ }^{90} \mathrm{Sr}$ and ${ }^{137} \mathrm{Cs}$ total stock in avian biomass annually migrating through the Chernobyl zone (5235 tons [2]).

\begin{tabular}{|l|c|c|c|c|c|c|}
\hline \multirow{2}{*}{\multicolumn{1}{c|}{ Indexes }} & \multicolumn{2}{c|}{1987} & \multicolumn{2}{c|}{2004} & \multicolumn{2}{c|}{ Reduction ratio } \\
\cline { 2 - 7 } & ${ }^{137} \mathrm{Cs}$ & ${ }^{90} \mathrm{Sr}$ & ${ }^{137} \mathrm{Cs}$ & ${ }^{90} \mathrm{Sr}$ & ${ }^{137} \mathrm{Cs}$ & ${ }^{90} \mathrm{Sr}$ \\
\hline $\mathrm{TF}, \mathrm{m}^{2} / \mathrm{kg}$ & $7.70 \mathrm{E}-03^{*}$ & $1.07 \mathrm{E}-02 *$ & $7.00 \mathrm{E}-04$ & $2.64 \mathrm{E}-03$ & 11.0 & 4.05 \\
\hline Total stock in soil, $\mathrm{kBq}$ & $2.06 \mathrm{E}+12$ & $8.57 \mathrm{E}+11$ & $1.39 \mathrm{E}+12$ & $5.68 \mathrm{E}+11$ & 1.48 & 1.51 \\
\hline Average soil contamination, $\mathrm{kBq} / \mathrm{m}^{2}$ & 996.7 & 415.4 & 674.4 & 275.1 & 1.48 & 1.51 \\
\hline Activity concentration in birds, $\mathrm{kBq} / \mathrm{kg}$ & 7.68 & 4.45 & 0.472 & 0.726 & 16.3 & 6.12 \\
\hline Total stock in birds, $\mathrm{GBq}$ & 40.2 & 23.3 & 2.47 & 3.80 & 16.26 & 6.12 \\
\hline Total stock in birds, $\mathrm{GBq}$ & $55.5-203.5^{*}$ & $14.8-66.6^{*}$ & & & & \\
\hline
\end{tabular}

*Data by [2].

Obviously, both these models are highly sensitive to estimates for bird densities and biomass and the percentage of migratory species. For example our estimates of the number of resident small sized birds is 12.4 times greater than those by [2], and 3.3 times higher for biomass. Ukrainian ornithologists (e.g. A. Poluda, person. comm.) consider existing assessments of seasonal avian flow through the region as very preliminary as nobody has counted birds in any systematic manner for the entire zone. It is quite possible that our estimates could be inaccurate by as much as one or even two order so magnitude. However even the maximum estimated radionuclide export amounts via birds appear to be negligible when compared to exports via surface and ground water movement [1].

\section{Acknowledgments}

The research described above was made possible in part by Award No. UB1-2507-KV-03 of the U.S. Civilian Research \& Development Foundation. 


\section{References}

[1] Kholosha V.I., Proskura N.I., Ivanov Y.A. et al. "Comparative estimation of radioecological significance of natural and technogenic objects of exclusion zone". In: Radiation Legacy of the 20th century: Environmental restoration (IAEA, Vienna. IAEA-TECDOC-1280. 2002) 159-170.

[2] Frantsevich L.I., Sabinevsky, B.V., Komissar A.D. et al. Radionuclide carrying-out by migratory birds. Radiobiology. 32, (1992) 357-363.

[3] Gaschak S.P., Maklyuk Y.A., Maksimenko A.M. et al. Features of radioactive contamination of small birds in the Chernobyl zone in 2003-2005. Radiobiology. Radioecology 48, (2008) 28-47.

[4] Brisbin I.L.Jr. Avian radioecology. In: Current ornithology (Plenum Publ. Corp., New York. 1991) 8, 69-140.

[5] Makluk Yu. A., Gaschak S.P., Maksimenko A.M. et al. Estimation of ${ }^{90} \mathrm{Sr}$ and ${ }^{137} \mathrm{Cs}$ excretion parameters from the organism of wild and laboratory small mammals in vivo, after natural contamination in the Chernobyl Zone. Radiobiology. Radioecology. 47, (2007) 444-456.

[6] Payevsky V.A. Demography of birds. In: Proceedings of Zoological Institute of Academy of Sciences of USSR. Vol. 125 (Leningrad, Nauka, 1985). 1-286.

[7] Davydchuk V.C. and Sorokina L.Yu. Map of anthropogenic changes of landscapes and actual vegetation of the Chernobyl NPP zone. Scale 1:100000. (Institute of Geography, Academy of Sciences of Ukraine. 1992).

[8] Gaschak S.P. Avifauna of the Evacuated Town of Pripyat. Vestnik of Zoology, Suppl. 14 (2000) 90-100.

[9] Nikiforov, M.E., Tishechkin, A.K., Samusenko I.E. et al. Forming of ornithocomplex structure and populations of model species of birds. In: Animal world in the zone of Chernobyl NPP's accident. Edited by Suschenya L.M. et al. (Minsk. Nauka I Tekhnika. 1995) 158-174.

[10] Schyogolev V.I. Quantitative registration of birds in the forest area. In: Investigation methods of productivity and structure of birds species within their habitats. Vol. 1. (Vilnius. 1977) 95-102.

[11] Zhezherin V.P. Ornithofauna of Ukrainian Polesye and its dependence on landscape conditions and anthropic factors. Species composition of the nesting birds, distribution on the territory, quantity, protection questions, zoogeography. Ph.D. Thesis. (Schmalhausen Institute of Zoology, Academy of Sciences of USSR, Kiev. 1969). 1-539.

[12] Ivanov Yu.A., Kashparov V.A. Long-term dynamics of the radiological situation in terrestrial ecosystems of the Chernobyl Exclusion Zone. Environmental science and pollution research. Sp. Iss. 1 (2003) 13-20. 